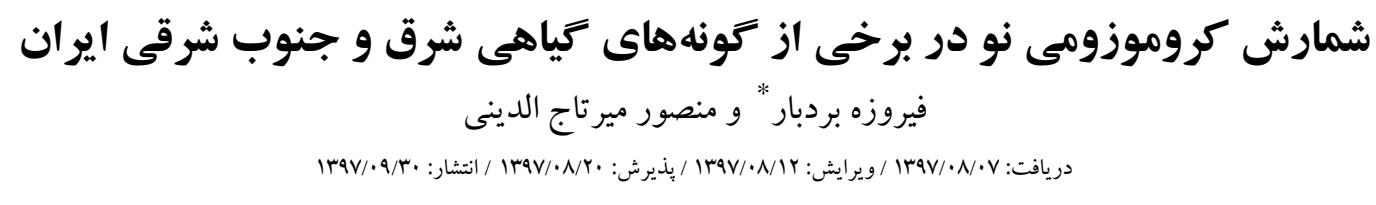

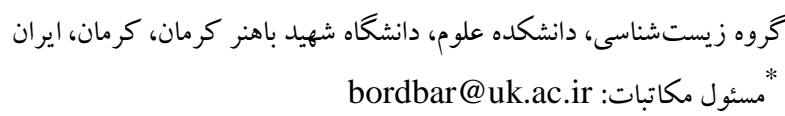

جكيده. در اين مطالعه عدد كروموزومى و كاريوتيب برخى از گُونهاى گياهى انحصارى كه در شرق و جنوب شرقى ايران يراكنش دارند، مورد بررسى

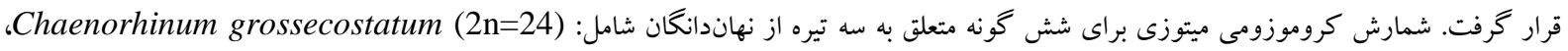
Gaillonia bruguieri $(2 \mathrm{n}=22)$ (بارهنگيان) Linaria iranica $(2 \mathrm{n}=12)$ ، Nanorrhinum campyloceras $(2 \mathrm{n}=18)$ Nepeta rivularis، و و (نعنائيان) براى اولين بار ارائه شده است. N. assurgens (2n=18)

$$
\text { وازههاى كليدى. ايران، عدد كروموزومى، كاريوتيب، گونه انحصارى، ميتوز }
$$

\title{
New chromosome counts in some plant species from east and south-east Iran
}

Firouzeh Bordbar* \& Mansour Mirtadzadini

Received: 19.10.2018 / Revised: 03.11.2018 / Accepted: 11.11.2018 / Published: 21.12.2018

\begin{abstract}
Department of Biology, Faculty of Sciences, Shahid Bahonar University of Kerman, Kerman, Iran *Correspondent author: bordbar@uk.ac.ir
\end{abstract}

\begin{abstract}
In this study, we investigated the chromosome numbers of some endemic species distributed in East and South-East Iran. The mitotic chromosome counts were presented for the first time for six species in three angiosperm families including: Linaria iranica $(2 \mathrm{n}=12)$, Nanorrhinum campyloceras $(2 \mathrm{n}=18)$, Chaenorhinum grossecostatum $(2 \mathrm{n}=24)$ (Plantaginaceae), Gaillonia bruguieri (Rubiaceae) $(2 \mathrm{n}=22)$, Nepeta rivularis and N. assurgens (Lamiaceae) $(2 \mathrm{n}=18)$.
\end{abstract}

Keywords. chromosome number, endemic species, Iran, karyotype, mitosis

\section{INTRODUCTION}

Chromosomal investigations were beneficial to systematics and evolutionary biology and are powerful sources for the clarification of the affinity among the taxa in molecular systematics (Soltis, 2014). In this study six taxa mostly endemic, growing in different localities of east and southeast of Iran were examined. The aim of this study was to determine the somatic chromosome number and karyotypes for Linaria iranica Hamdi \& Assadi, Chaenorhinum grossecostatum Speta, Nanorrhinum campyloceras (Aellen \& Esfand.) Naanaie, Assadi \& Tavassoli, Gaillonia bruguieri A.Rich. ex DC.,
Nepeta assurgens Hausskn. \& Bornm. ex Bornm. and Nepeta rivularis Bornm. for the first time.

\section{MATERIALS AND METHODS}

For the study of karyotypes, online data bases, as well as related literatures, were used to assess the previous chromosomal works on the examined taxa. Seeds and herbarium specimens of studied materials were collected from natural habitats (Table 1). The seeds of Linaria iranica were obtained from the isotype specimen. The vouchers were deposited in MIR herbarium. We used squash method according to Payandeh et al. 2015. 
For this purpose, seeds were germinated on wet filter paper in Petri dishes at $25{ }^{\circ} \mathrm{C}$. Roots with 1-2 $\mathrm{cm}$ length were pretreated for $5 \mathrm{~h}$ in $\alpha$ monobromonaphthalene at $4{ }^{\circ} \mathrm{C}$ and washed and fixed in Carnoy I solution (3:1 absolute ethanol:glacial acetic acid) for 24 hours. At the next fixation step, hydrolysis was carried out in $1 \mathrm{~N} \mathrm{HCl}$ at $60{ }^{\circ} \mathrm{C}$ for $2 \mathrm{~min}$. Then, the roots were washed and stained in aceto-iron hematoxilin for $24 \mathrm{~h}$ at 30 ${ }^{\circ} \mathrm{C}$. The roots were gently squashed in $45 \%$ acetic acid on a glass slide. The images of the clearest mitotic metaphases of 5-10 cells were taken using an Olympus BH-2 light microscope equipped with camera photomicrograph system.

Table. 1. Name of the plant species, locality information and chromosome numbers.

\begin{tabular}{|c|c|c|}
\hline Taxon & Locality information & $\begin{array}{c}\text { Chromosome } \\
\text { number }\end{array}$ \\
\hline \multicolumn{3}{|l|}{ Plantaginaceae } \\
\hline Linaria iranica Hamdi \& Assadi & $\begin{array}{c}\text { Iran, SE, Kerman, Jiroft, Rud farq, 03.IV.1996, } \\
\text { Mirtadzadini } 2000 \text { (MIR) }\end{array}$ & $2 n=12$ \\
\hline $\begin{array}{c}\text { Chaenorhinum grossecostatum } \\
\text { Speta }\end{array}$ & $\begin{array}{c}\text { Iran, SE, Kerman, Rayen, Hossein Abad, N29²0' } \\
\text { 39.79", E5 } 7^{\circ} 28^{\prime} 35.22 ", 2267 \text { m, 31.V.2015, Bordbar } \\
2907 \text { (MIR) }\end{array}$ & $2 n=24$ \\
\hline $\begin{array}{l}\text { Nanorrhinum campyloceras } \\
\text { (Aellen \& Esfand.) Podlech \& } \\
\text { Iranshahr }\end{array}$ & $\begin{array}{c}\text { Iran, SE, Kerman, Jiroft to Deh-Bakri, N28 49' } \\
\text { 09.02", } 57^{\circ} 48^{\prime} 09.02^{\prime \prime}, 1269 \mathrm{~m}, 01 . \text { VI.2015, Bordbar } \\
2908 \text { (MIR) }\end{array}$ & $2 \mathrm{n}=18$ \\
\hline \multicolumn{3}{|l|}{ Rubiaceae } \\
\hline $\begin{array}{c}\text { Gaillonia bruguieri A.Rich. ex } \\
\text { DC. }\end{array}$ & $\begin{array}{c}\text { Iran, E: Khorasan, N Nehbandan, E Kalata Seied Ali } \\
\text { village, N31 37' 15.5", E6 } \\
0^{\circ} 01^{\prime} 13.8^{\prime \prime}, 1435 \mathrm{~m}, 02 . \mathrm{V} .2017 \text {, Mirtadzadini and } \\
\text { Jafari } 2373 \text { (MIR). }\end{array}$ & $2 n=22$ \\
\hline \multicolumn{3}{|l|}{ Lamiaceae } \\
\hline $\begin{array}{l}\text { Nepeta assurgens Hausskn. \& } \\
\text { Bornm. ex Bornm. }\end{array}$ & $\begin{array}{l}\text { Iran, SE, Kerman, North of mt. Lalehzar, near the } \\
\text { point N29 } 28^{\prime} 20.14 ", \text { E56 } 46^{\circ} 28.06 " \text {, ca. } 3000 \text { m, } \\
\text { 08.VIIII.2017, Bordbar } 2909 \text { (MIR). }\end{array}$ & $2 \mathrm{n}=18$ \\
\hline Nepeta rivularis Bornm. & $\begin{array}{l}\text { Iran, SE, Kerman, North of mt. Lalehzar, ca. } 3000 \text { m, } \\
\text { Mirtadzadini } 2384 \text { (MIR). }\end{array}$ & $2 \mathrm{n}=18$ \\
\hline
\end{tabular}

\section{RESULTS AND DISCUSSION}

The karyotypes of the taxa examined are presented in Fig. 1.

\section{Linaria iranica (Plantagiaceae)}

The results of this study revealed $2 n=12$ and $x=6$ for Linaria iranica (Fig. 1. A). Linaria Miller with about 200 taxa is the largest and worldwide distributed genus of the tribe Antirrhineae Chav. (Sutton, 1988). Linaria species include 35 species of annual or perennial herbs in Iran, which are distributed in all parts of the country (Hamdi \& Assadi, 2011). According to Hamdi \& Assadi (2011) Linaria iranica belongs to sect. Versicolores
(Benth.) Wettst. This species is an annual herb and narrow endemic species restricted to a very small area in South-East Iran (Hamdi \& Assadi, 2011; Podlech \& Iranshahr, 2015). Since the first report (Hamdi et al., 2008), no additional observations of the species have been made in the field. This can be an indication of its endangered conservation status. The basic chromosome numbers reported for Linaria up till now are $\mathrm{x}=6,7,9,12$ and 13, however, the highest frequent chromosome number reported is $2 \mathrm{n}=12$ (Ranjbar \& Nouri, 2015). Therefore, the chromosome number $2 \mathrm{n}=12$ for $L$. iranica is in accordance with previous counts for Linaria. 


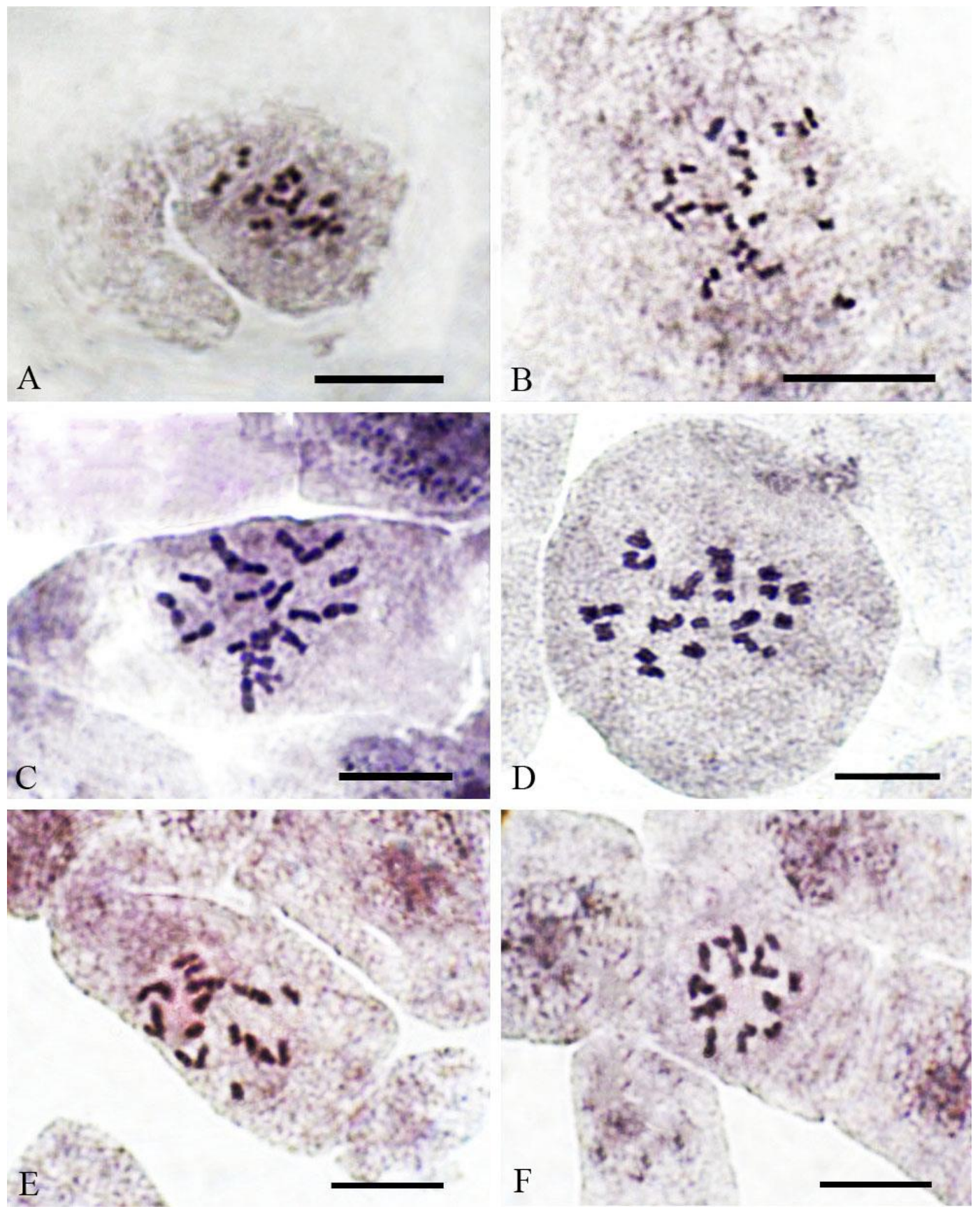

Fig. 1. Somatic chromosomes of A: Linaria iranica, B: Chaenorhinum grossecostatum, C: Nanorrhinum campyloceras, D: Gaillonia bruguieri, E: Nepeta assurgens and F: Nepeta rivularis .Scale bar $=10 \mu \mathrm{m}$.

\section{Chaenorhinum grossecostatum (Plantagiaceae)}

The results of this study revealed $2 \mathrm{n}=24$ for Chaenorhinum grossecostatum (Fig. 1. B). Chaenorhinum (DC.) Rchb., including annual herbs, is a genus belonging to the sect. Microrrhinum (Endl.) D.A.Sutton, tribe Antirrhineae that has four species in Iran (Podlech \& Iranshahr, 2015). This is a narrow endemic species which is distributed in Kerman province, located in South-East Iran (Hamdi \& Assadi, 2011).
Among Chaenorhinum species, the chromosome count was reported for Chaenorhinum rodriguezii (Porta) L. Sáez \& Vicens $(2 n=14)$ (Castro \& Rosselló, 2007) and according to Index to Plant Chromosome Numbers (IPCN) (Goldblatt \& Johnson, 1979-) for Ch. minus (L.) Lange ( $2 \mathrm{n}=14$ and 28), Ch. origanifolium (L.) Fourr. $(2 n=14), C h$. tenellum Lange $(2 \mathrm{n}=14)$ and $C h$. villosum Lange $(2 \mathrm{n}=14)$. Therefore, $2 \mathrm{n}=24$ (in $C$. grossecostatum) has not been reported before among Chaenorhinum species. 


\section{Nanorrhinum campyloceras (Plantagiaceae)}

The results of this study revealed $2 \mathrm{n}=18$ and $\mathrm{x}=9$ for Nanorrhinum campyloceras (Fig. 1. C). Nanorrhinum Betsche, including perennial subshrubs or herbs, belongs to the tribe Antirrhineae, which has four species in Iran (Podlech \& Iranshahr, 2015) of which N. campyloceras, is an endemic species distributed in South and South-East Iran (Hamdi \& Assadi, 2011). The chromosome number of $2 n=18$ have been previously reported for Nanorrhinum species ( $N$. asparagoides (Schweinf.) Ghebr., $N$. heterophyllum (Schousb.) Ghebr., $N$. ramosissimum (Wall.) Betsche, and $N$. woodii (D.A.Sutton) Ghebr.) (Ghebrehiwet, 2001). Therefore, the results of the present work are in accordance with the results of previous reports.

\section{Gaillonia bruguieri (Rubiaceae)}

The results of this study indicated $2 \mathrm{n}=22$ and $\mathrm{x}=11$ for Gaillonia bruguieri (Fig. 1. D). Gillonia A. Rich. ex DC. consists of small subshrub or perennial herbs mainly distributed in semi-deserts of Irano-Turanian region of the world (Ehrendorfer \& Schönbeck-Temesy, 2005). G. bruguieri is the main and most abundant species of Gaillonia in Iran also existing in Afghanistan and Iraq. According to the literature, only the chromosome number of G. macrantha Blatt. \& Hallb. has been recorded so far (Khatoon \& Ali, 1993). The chromosome number of this species was $2 \mathrm{n}=22$, so the number $\mathrm{x}=11$ for $G$. bruguieri is in accordance with the previous report for this genus.

\section{Nepeta assurgens and $N$. rivularis (Lamiaceae)}

The results of this study revealed $2 \mathrm{n}=18$ and $\mathrm{x}=9$ for both Nepeta assurgens and $N$. rivularis (Fig. 1. $\mathrm{E}$ and $\mathrm{F}$, respectively). This is the first chromosome count for these species.

Nepeta L. belongs to the family Lamiaceae and subfamily Nepetoideae, tribe Mentheae (Cantino et al., 1992). Nepeta species are perennial, rarely annual, herbaceous and fruticose plants and consist of 300 species in the world (Jamzad et al., 2003). The majority of the recorded data in various studies revealed that $x=8$ and $x=9$ were the most common primary basic chromosome numbers of the genus and the original basic numbers for Lamiaceae family. The other basic chromosome numbers are considered to be secondarily evolved (Srivastava, 2012). Previous studies (Saggoo et al., 2011; Kharazian et al., 2013; Payandeh et al., 2015) have frequently reported $2 \mathrm{n}=18$ in Nepeta, which support the classical view of $\mathrm{x}=9$ as a primary basic number. Nepeta rivularis and $N$. assurgens are perennial herbs and narrow endemic species restricted to a very small area in South East Iran (Rechinger, 1982; Jamzad, 2012). The chromosome number of these species $(2 n=18)$ is in accordance with the previous report for this genus.

\section{ACKNOWLEDGEMENT}

This study was supported by a greatly appreciated grant from Shahid Bahonar University of Kerman.

\section{REFERENCES}

Cantino, P.D., Harley, R.M. and Wagstaff, S.J. 1992. Genera of Lamiaceae: status and classification. In: Harley, R.M., Reynolds, T. (eds.), Advances in Labiatae science. - Royal Botanic Gardens, Kew. pp: 511-523.

Castro, M. and Rosselló J.A. 2007. Karyological observations on plant taxa endemic to the Balearic Islands. - Bot. J. Linn. Soc. 153: 463-476.

Ehrendorfer, F. and Schönbeck-Temesy, E. 2005. Gaillonia. - In: Rechinger, K.H. (ed.), Flora Iranica, vol. 176: 22-38. - Akad. Druck- und Verlagsanstalt, Graz.

Ghebrehiwet, M. 2001. Taxonomy, phylogeny and biogeography of Kickxia and Nanorrhinum (Scrophulariaceae). - Nord. J. Bot. 20: 655-690.

Goldblatt P., Johnson D.E. (eds.). 1979. Index to plant chromosome numbers. St. Louis: Missouri Botanical Garden. http://mobot.mobot.org/W3T/Search/ipcn.html [accessed 22 Oct. 2018].

Hamdi, M.M. and Assadi, M. 2011. Linaria. - In: Assadi et al. (eds.), Flora of Iran. vol. 68. - RIFR., Tehran.

Hamdi, M.M., Assadi, M., Vaezi, G. and Mirtadzadini, M. 2008. A New Species of Linaria Sect. Versicolores (Scrophulariaceae) from Iran. Novon 18: 340-343.

Kharazian, N., Zamani Shourabi, S. and Yousefi, M. 2013. Chromosome count and karyotype study of eleven Nepeta L. (Lamiaceae) species from Iran. - Bio. Di. Con. 6: 76-87.

Khatoon, S. and Ali, S.I. 1993. Chromosome Atlas of the Angiosperms of Pakistan. - University of Karachi, Karachi.

Jamzad, Z., Grayer, R.J., Kite, G.C., Monique, S.J., Simmonds, M.I. and Jalili, A. 2003. Leaf surface flavonoids in Iranian species of Nepeta (Lamiaceae) and some related genera. - Biochem. Syst. Ecol. 31: $587-600$.

Jamzad, Z. 2012. Nepeta. - In: Assadi, M., Maassoumi, A. A. and Mozaffarian. V. (eds.), Flora of Iran. vol. 76: 454-609. - RIFR., Tehran.

Payandeh, M., Bordbar, F., Mirtadzadini, M. and Bakhshi Khaniki, G.R. 2015. New chromosome counts for Nepeta (Lamiaceae) from flora of Iran. Bio. Di. Con. 8: 70-73. 
Podlech, D. and Iranshahr, M. 2015. Scrophulariaceae II, Antirrhineae. - In: Rechinger, K.H. (ed.), Flora Iranica. Vol. 180: 30-71. - Akad. Druck- und Verlagsanstalt, Graz.

Ranjbar, M. and Nouri, S. 2015. Biogeography of the Genus Linaria (Plantaginaceae) Based on Chromosome Number Data. - J. Cell Mol. Med. 7: 115-132.

Rechinger, K.H. 1982. Lamiaceae. - In: Rechinger, K.H. (ed.), Flora Iranica. vol. 150: 108-216. Akad. Druck- und Verlagsanstalt, Graz.

Saggoo, M.I.S., Srivastava, D.K. and Grewal, P. 2011. Meiotic studies in 14 species of the Nepeta L. (Lamiaceae) from cold desert regions of Lahaul-Spiti and adjoining areas of Northwest-Himalaya, India. - Cytologia 76: 231236.
Soltis, D.E. 2014. Chromosome data. - Iran. J. Bot. 20: 228-229.

Srivastava, D.K. 2012. Cyto-morphological diversity in species of Labiatae and Scrophulariaceae from Lahaul-Spiti and adjoining areas. Ph. D. Thesis. Department of Botany, Punjabi University Patiala, Patiala, Punjab, India.

Sutton, D.A. 1988. A revision of the tribe Antirrhineae (Scrophulariaceae). - Oxford University Press, Oxford.

$* * * * *$

How to cite this article:

Bordbar, F., and Mirtadzadini, M. 2018. New Chromosome counts in some plant species from east and south-east Iran. - Nova Biol. Reperta 5 (3): 257261. 